\title{
ETRUMEUS GOLANII (ACTINOPTERYGII: CLUPEIFORMES: DUSSUMIERIIDAE) A NEW LESSEPSIAN MIGRANT RECORDED IN MOROCCO, ALBORAN SEA (SOUTH-WEST MEDITERRANEAN)
}

\author{
Mohamed Naoufal TAMSOURI ${ }^{*}$, Said BENCHOUCHA ${ }^{1}$, Mohamed IDHALLA ${ }^{2}$, \\ and Fatima EL AAMRI ${ }^{3}$
}

${ }^{1}$ Laboratory of Fisheries, National Institute of Fisheries Research (INRH), Tanger, Morocco

${ }^{2}$ Department of Aquaculture, National Institute of Fisheries Research (INRH), Casablanca, Morocco

${ }^{3}$ Shellfish Aquaculture Technology Research Center, National Institute of Fisheries Research (INRH), M'diq, Morocco

Tamsouri M. N., Benchoucha S., Idhalla M., El Aamri F. 2019. Etrumeus golanii (Actinopterygii: Clupeiformes: Dussumieriidae) a new Lessepsian migrant recorded in Morocco, Alboran Sea (southwest Mediterranean). Acta Ichthyol. Piscat. 49 (1): 43-47

\begin{abstract}
The occurrence of a Lessepsian migrant, the Golani round herring, Etrumeus golanii DiBattista, Randall et Bowen, 2012, is reported here for the first time from the Alboran Sea (south-west Mediterranean). On May 2018, twenty individuals were caught by a commercial purse-seiner off Fnideq (Morocco), but five females and two males, were kept by the fisherman for further analyses. This new finding confirms the expansion of this Lessepsian migrant throughout the Mediterranean Sea.
\end{abstract}

Keywords: round herring, Etrumeus golanii, new record, morphometry, Alboran Sea, Morocco

\section{INTRODUCTION}

The opening of the Suez Canal in 1869 connected the Red Sea to the Mediterranean Sea and allowed a large number of tropical/subtropical marine species to enter the Mediterranean basin. This migration phenomenon has been called Lessepsian migration (DiBattista et al. 2012, Galil et al. 2015). To date, many Lessepsian species have established thriving populations along the eastern Mediterranean coastlines (Galil et al. 2017).

According to a recent study by Zenetos et al. (2017), a total of 821 alien species have been reported in the Mediterranean Sea with the Lessepsian fishes accounting for approximately 100 (Giovos et al. 2018), including the Golani round herring, Etrumeus golanii DiBattista, Randall et Bowen, 2012.

Etrumeus golanii is an inshore pelagic fish originally known from the northern region of the Red Sea and now expanding towards the Mediterranean. It is established in the Mediterranean Sea, especially in its eastern part and was widely reported in the literature as "Etrumeus teres". Those erroneously labelled findings later turned out to be a species that is new to science (Zenetos et al. 2017). The above-mentioned misidentification was exposed by DiBattista et al. (2012).

Etrumeus golanii is not restricted to the eastern Mediterranean Sea but it is also present in its central (Italy,
Libya and Tunisia) and western (Algeria) parts (Falautano et al. 2006, Boussellaa et al. 2016, Shakman et al. 2017, Stamouli et al. 2017).

This paper reports the first occurrence of Etrumeus golanii for Morocco and the Alboran Sea and the second record of this fish from the western Mediterranean Sea.

\section{MATERIAL AND METHODS}

Severalspecimens of the Golaniround herring,Etrumeus golanii, were caught off Fnideq, Morocco (35 $50.366^{\prime}$ $\mathrm{N}, 005^{\circ} 16.578^{\prime} \mathrm{W}-35^{\circ} 49.998^{\prime} \mathrm{N}, 005^{\circ} 16.388^{\prime} \mathrm{W}$ ) (Fig. 1) from depths ranging from 67 to $80 \mathrm{~m}$, at nights of 7 and 8 May 2018, by a commercial purse-seiner. The catch included also other small pelagic fishes such as Trachurus mediterraneus (Steindachner, 1868), Scomber colias Gmelin, 1789, and Sardina pilchardus (Walbaum, 1792). Seven specimens of the round herring were provided by the fisherman for our study.

All specimens were measured, weighed, and photographed. Morphometric and meristic measurements are presented in Table 1. The specimens were preserved in ethanol and deposited at the Laboratory of Fisheries of the National Institute of Fisheries Research (INRH), Tanger, Morocco, with voucher number LP-18/01. 


\section{RESULTS}

According to the description given by DiBattista et al. (2012) and comparison of the morphometric and metric characters of Etrumeus golanii from other areas of the central and eastern Mediterranean Sea (Golani 2000, Falautano et al. 2006, Akyol and Ulaş 2016, Boussellaa

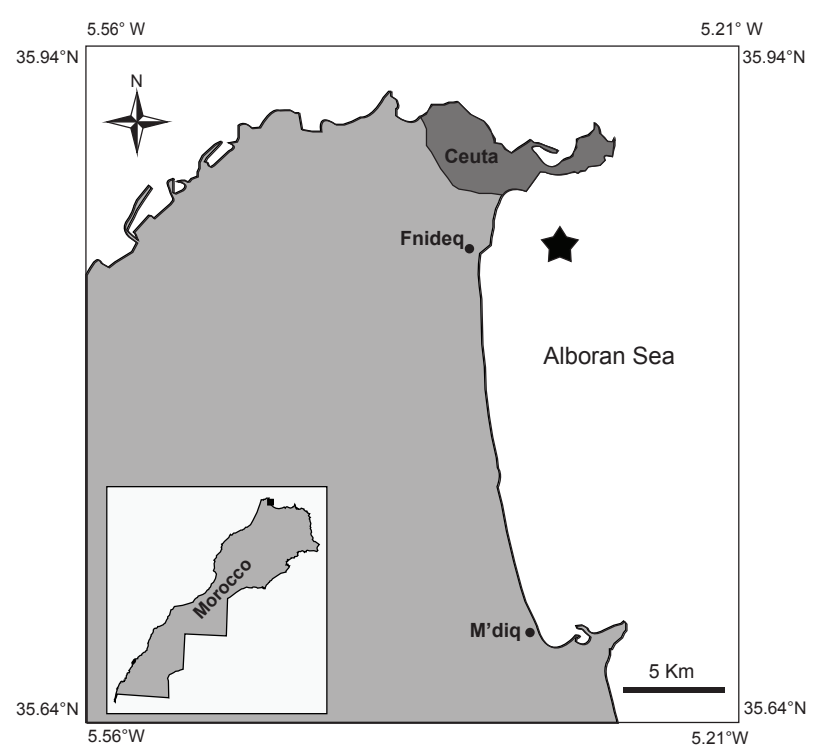

Fig. 1. The capture site of Etrumeus golanii specimens (star); off Fnideq, Morocco (Alboran Sea) et al. 2016) (Table 1), we have identified our specimens as Etrumeus golanii. All studied specimens were adults with a total length (TL) varying from 252 to $283 \mathrm{~mm}$ and net weight varying from 148.66 to 217.39 g (Fig. 2). These specimens were dissected and sexed. Thus, five were identified as females with gonad weighing from 2.57 to $4.48 \mathrm{~g}$ and two were males with gonad weight from 1.86 to $6.57 \mathrm{~g}$.

\section{DISCUSSION}

To date, there is no evidence of any negative impact of Etrumeus golanii on local fisheries resources. On the contrary, the presence of E. golani received positive comments (Stamouli et al. 2017). In the eastern Mediterranean Sea, an important population of the Golani round herring is already established (Corsini et al. 2005, Akyol and Ulaş 2016) and represents an important commercial resource (DiBattista et al. 2012). The currently known distribution of the species in the Mediterranean is shown in Fig. 3 and listed in Table 2. With this finding, the number of Lessepsian species present in Morocco increases to two (see below).

In general, there has been a limited number of studies on non-indigenous species, conducted along the Mediterranean coasts of Morocco (Bazairi et al. 2016, Selfati et al. 2017, El Aamri et al. 2018) and Lessepsian species, in particular. Selfati et al. (2017) reported the

Table 1

Morphometric measurements and counts of Etrumeus golanii, captured from Findeq Bay, Morocco (Alboran Sea) compared with other published records

\begin{tabular}{|c|c|c|c|c|c|}
\hline & Cyprus 2000 & Italy 2006 & Turkey 2016 & Tunisia 2016 & Morocco 2018 \\
\hline$n$ & 2 & 1 & 1 & 7 & 7 \\
\hline \multicolumn{6}{|l|}{ Measurements [mm] } \\
\hline Total length & - & 231 & 180 & $225-265$ & $252-283$ \\
\hline Fork length & - & 211 & 159 & $200-243$ & $228-260$ \\
\hline Standard length & $138-213$ & 202 & 153 & $165-225$ & $215-243$ \\
\hline Body depth & $20.6-42.4$ & 35.6 & 28 & $34.5-41.3$ & $43-50$ \\
\hline Predorsal fin length & - & 88 & 66 & $87-102$ & $92-107$ \\
\hline Prepectoral fin length & - & - & 38 & - & $46.5-56$ \\
\hline Preanal fin length & - & - & 127 & - & $175-203$ \\
\hline Head length & $31-53.5$ & 45 & 34 & $39.2-49.3$ & $45-52$ \\
\hline Eye diameter & $9.3-18.6$ & 12.44 & 11 & $10.2-12.5$ & $13-15$ \\
\hline Preorbitary length & - & - & 12 & - & $13-16$ \\
\hline Dorsal fin base length & - & 26.6 & - & $24.2-26.1$ & $31-35$ \\
\hline Anal fin base length & - & 9.4 & - & $9-9.5$ & $9-12$ \\
\hline Pelvic fin length & - & 14.3 & - & $14-22$ & $14-16$ \\
\hline \multicolumn{6}{|l|}{ Meristic counts } \\
\hline Dorsal fin rays & $17-20$ & 18 & 17 & 18 & 18 \\
\hline Pectoral fin rays & $15-17$ & 15 & 16 & 16 & $15-16$ \\
\hline Pelvic fin rays & $8-10$ & 8 & 8 & 8 & 8 \\
\hline Anal fin rays & $9-10$ & 12 & 9 & 9 & $9-10$ \\
\hline
\end{tabular}

$n=$ number of specimens examined, Cyprus $2000=$ Golani 2000, Italy $2006=$ Falautano et al. 2006, Turkey $2016=$ Akyol and Ulaş 2016, Tunisia 2016 = Boussellaa et al. 2016, Morocco $2018=$ presently reported study. 
Records of Etrumeus golanii in the Mediterranean Sea

\begin{tabular}{cll}
\hline Record date & \multicolumn{1}{c}{ Location } & \multicolumn{1}{c}{ Reference } \\
\hline 1961 & Haifa Bay, Israel & Whitehead 1963 \\
1994 & Egypt & El Sayed 1994 \\
1996 & Iskenderun, Turkey & Başusta et al. 1997 \\
1997 & Antalya Gulf, Turkey & Yilmaz and Hoşsucu 2003 \\
1999 & Limassol, Cyprus & Golani 2000 \\
2003 & Rhodes, Greece & Corsini et al. 2005 \\
2004 & Cyclades, Greece & Kallianiotis and Lekkas 2005 \\
2005 & Hydra Island, Greece & Zenetos et al. 2008 \\
$2004-2005$ & Crete, Greece & Kasapidis et al. 2007 \\
2005 & Lampedusa, Italy & Falautano et al. 2006 \\
2009 & Dikili Coast, Turkey & Yarmaz et al. 2010 \\
2015 & Gulf of Izmir, Turkey & Akyol and Ulaş 2016 \\
2014 & Gulf of Gabes, Tunisia & Boussellaa et al. 2016 \\
2017 & Misrata, Libya & Shakman et al. 2017 \\
2017 & Cherchell, Algeria & Stamouli et al. 2017 \\
2018 & Fnideq Bay, Morocco & Presently reported study \\
\hline
\end{tabular}

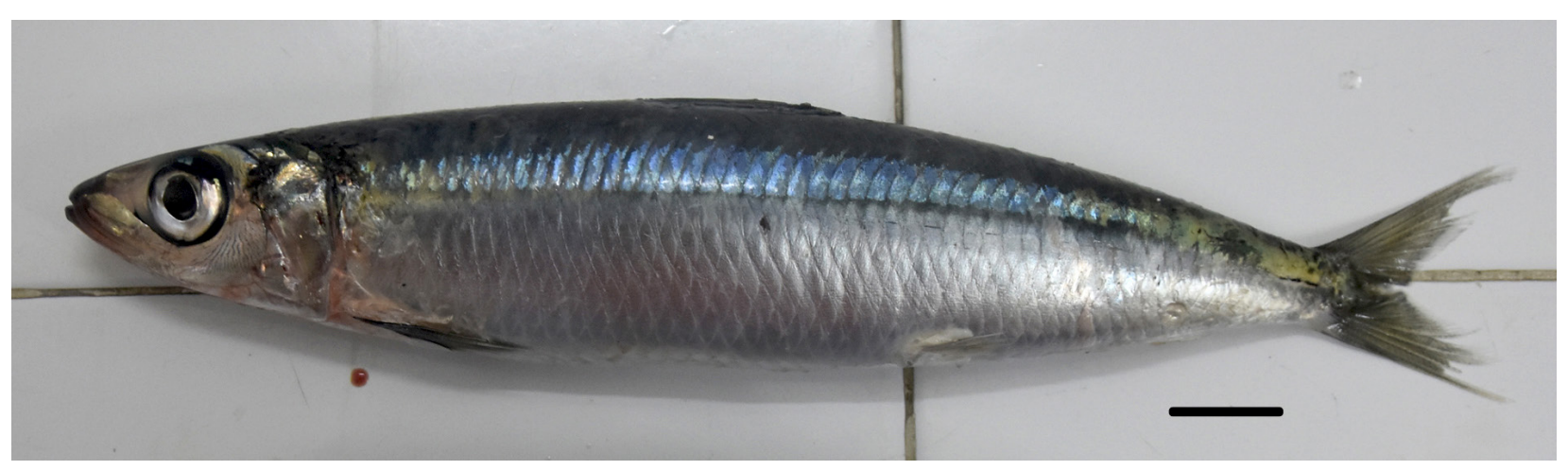

Fig. 2. Etrumeus golanii captured off Fnideq Bay, Morocco; scale bar: $20 \mathrm{~mm}$

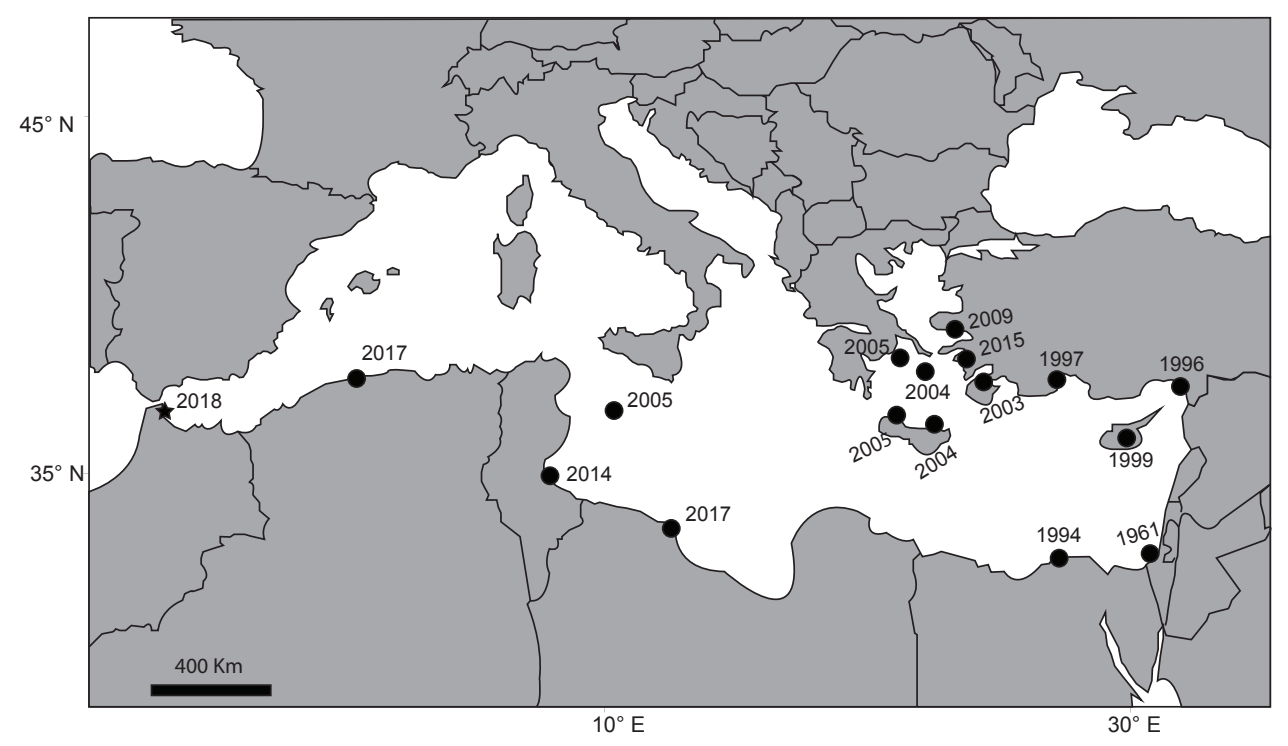

Fig. 3. Published records of Etrumeus golanii in the Mediterranean Sea (black dots: as listed in Table 2) and the new record, determined in this study (star) 
first presumed Lessepsian species namely, the gastropod Bursatella leachii from Mar-Chica (Nador).

In conclusion, the recent occurrence of the Golani round herring, Etrumeus golanii, in Tunisian, Algerian, and Moroccan waters, may be linked to the altering environmental conditions which are gradually becoming more favourable for those fish. In this case, it could be assumed that the establishment of a sustainable population in near future could be expected. Furthermore, the presently reported record confirms, also, the occurrence of this fish species in the Alboran Sea and its expansion throughout the Mediterranean Sea.

\section{ACKNOWLEDGEMENTS}

We gratefully acknowledge the help of Dr Manuel Antonio E. Malaquias in proofreading the text.

We would like to thank, also, $\mathrm{Mr}$ Abdelghani EL HAMDI, captain of the commercial purse-seiner Hilal 3 from M'diq port, for providing us specimens and information on the E. golanii fishing localities and Khalil TAMSOURI for making the illustrations.

\section{REFERENCES}

Akyol O., Ulaş A. 2016. The second record of Lessepsian migrant Etrumeus golanii from the north-eastern Aegean Sea (Izmir Bay, Turkey). Annales, Series historia naturalis 26 (1): 25-28. DOI: 10.19233/ ASHN.2016.4

Başusta N., Erdem Ü., Mater S. 1997. İskenderun Körfezi'nde yeni bir Lesepsiyen göçmen balık türü; Kızılgözlü Sardalya, Etrumeus teres (Dekay, 1842). [A new species of Lessepsian migratory fish in the Gulf of Iskenderun-The red-eyed sardine, Etrumeus teres (Decay, 1842).] Pp. 921-924. In: Akdeniz Balıç̧ılık Kongresi Mediterranean Fisheries Congress, 9-11 Nisan/April 1997, Izmir, Turkey. [In Turkish.]

Bazairi H., Sghaier Y.R., Benhoussa A., Boutahar L., El Kamcha R., Selfati M., Gerovasileiou V., Baeza J., Castañer V., Martin J., Valriberas E., González R., Maestre M., Espinosa F. Ouerghi A. 2016. Maroc: Site de Jbel Moussa. Cartographie des habitats marins clés de Méditerranée et initiation de réseaux de surveillance. PNUE/PAM-CAR/ASP- Projet MedKeyHabitats, Tunis.

Boussellaa W., Boudaya L., Derbel H., Neifar L. 2016. A new record of the Lessepsian fish Etrumeus golanii (Teleostei: Clupeidae) in the Gulf of Gabes, Tunisia, with notes on its parasites. Cahiers de Biologie Marine 57 (4): 389-395. DOI: 10.21411/CBM.A.843F287A

Corsini M., Margies P., Kondilatos G., Economidis P.S. 2005. Lessepsian migration of fishes to the Aegean Sea: First record of Tylerius spinosissimus (Tetraodontidae) from the Mediterranean and six more fish records from Rhodes. Cybium 29 (4): 347-354.

DiBattista J.D., Randall J.E., Bowen B.W. 2012. Review of the round herrings of the genus Etrumeus (Clupeidae: Dussumieriinae) of Africa, with descriptions of two new species. Cybium 36 (3): 447-460.
El Aamri F., Idhalla M., Tamsouri M.N. 2018. Occurrence of the invasive brown seaweed Rugulopteryx okamurae (E.Y. Dawson) I.K. Hwang, W.J. Lee et H.S. Kim (Dictyotales, Phaeophyta) in Morocco (Mediterranean Sea). Mediterranean Fisheries and Aquaculture Research 1 (2): 92-96.

El-Sayed R.S. 1994. Check-list of Egyptian Mediterranean fishes. National Institute of Oceanography and Fisheries, Alexandria, Egypt.

Falautano M., Castriota L., Andaloro F. 2006. First record of Etrumeus teres (Clupeidae) in the Central Mediterranean Sea. Cybium 30 (3): 287-288.

Galil B.S., Boero F., Campbell M.L., Carlton J.T., Cook E., Fraschetti S., Gollasch S., Hewitt C.L., Jelmert A., Macpherson E., Marchini A., McKenzie C., Minchin D., Occhipinti-Ambrogi A., Ojaveer H., Olenin S., Piraino S., Ruiz G.M. 2015. "Double trouble": The expansion of the Suez Canal and marine bioinvasions in the Mediterranean Sea. Biological Invasions 17 (4): 973-976. DOI: 10.1007/s10530-0140778-y

Galil B., Marchini A., Occhipinti-Ambrogi A., Ojaveer H. 2017. The enlargement of the Suez Canal-Erythraean introductions and management challenges. Management of Biological Invasions 8 (2): 141-152. DOI: $10.3391 / \mathrm{mbi} .2017 .8 .2 .02$

Giovos I., Bernardi G., Romanidis-Kyriakidis R., Marmara D., Kleitou P. 2018. First records of the fish Abudefduf sexfasciatus (Lacepède, 1801) and Acanthurus sohal (Forsskål, 1775) in the Mediterranean Sea. BioInvasions Records 7 (2): 205210. DOI: 10.3391/bir.2018.7.2.14

Golani D. 2000. The Lessepsian migrant, the red-eye round herring, Etrumeus teres (DeKay, 1842), a new record from Cyprus. Zoology in the Middle East 20 (1): 61-64. DOI: 10.1080/09397140.2000.10637813

Kallianiotis A., Lekkas V. 2005. First documented report on the Lessepsian migrant Etrumeus teres De Kay, 1842 (Pisces: Clupeidae) in the Greek Seas. Journal of Biological Research 4: 225-229.

Kasapidis P., Peristeraki P., Tserpes G., Magoulas A. 2007. A new record of the Lessepsian invasive fish Etrumeus teres (Osteichthyes: Clupeidae) in the Mediterranean Sea (Aegean, Greece). Aquatic Invasions 2 (2): 152-154. DOI: 10.3391/ai.2007.2.2.12

Selfati M., El Ouamari N., Crocetta F., Mesfioui A., Boissery P., Bazairi H. 2017. Closing the circle in the Mediterranean Sea: Bursatella leachii Blainville, 1817 (Mollusca: Gastropoda: Anaspidea) has reached Morocco. BioInvasions Records 6 (2): 129-134. DOI: 10.3391/bir.2017.6.2.07

Shakman E.A., Ben Abdalha A., Talha F., AlFaturi A., Bariche M. 2017. First records of seven marine organisms of different origins from Libya (Mediterranean Sea). BioInvasions Records 6 (4): 377-382. DOI: 10.3391/bir.2017.6.4.13

Stamouli C., Akel E.H.Kh., Azzurro E., Bakiu R., Bas A.A., Bitar G., Boyacı Y.Ö., Cakalli M., CorsiniFoka M., Crocetta F., Dragičević B., Dulčić J., 
Durucan F., El Zrelli R., Erguden D., Filiz H., Giardina F., Giovos I., Gönülal O., Hemida F., Kassar A., Kondylatos G., Macali A., Mancini E., Ovalis P., Paladini de Mendoza F., Pavičić M., Rabaoui I., Rizkalla S. I., Tiralongo F., Turan C., Vrdoljak D., Yapici S., Zenetos A. 2017. New Mediterranean biodiversity records (December 2017). Mediterranean Marine Science 18 (3): 534-556. DOI: 10.12681/mms. 15823

Yarmaz A., Balaban C., Türkakın M., Türker-Çakır D. 2010. A new record of Lessepsian migrant Etrumeus teres (DeKay, 1842) (Osteichthyes: Clupeidae) from the northern Aegean Sea. Journal of Applied Ichthyology 26 (1): 134-136. DOI: 10.1111/j.14390426.2009.01365.x

Yılmaz R., Hoşsucu B. 2003. Some biological parameters of round herring, Etrumeus teres (De Kay, 1842) in the
Gulf of Antalya (Mediterranean Sea). Ege University Journal of Fisheries and Aquatic Sciences 20 (1-2): $1-8$.

Zenetos A., Çinar M. E., Crocetta F., Golani D., Rosso A., Servello G., Shenkar N., Turon X., Verlaque M. 2017. Uncertainties and validation of alien species catalogues: The Mediterranean as an example. Estuarine, Coastal and Shelf Science 191: 171-187. DOI: 10.1016/j.ecss.2017.03.031

Zenetos A., Vassilopoulou V., Salomidi M., Poursanidis D. 2008. Additions to marine alien fauna of Greek waters (2007 update). Marine Biodiversity Records 1: e91. DOI: 10.1017/S1755267207009281

Whitehead P.J.P. 1963. A revision of the recent round herrings (Pisces: Dussumieriidae). Bulletin of British Museum (Natural History) Zoology 10 (6): 305-380. DOI: 10.5962/bhl.part.20529

Received: 5 June 2018 Accepted: 24 August 2018 Published electronically: 15 March 2019 